\title{
PERSEPSI CORPORATE SOCIAL RESPONSIBILITIES (CSR) SEBAGAI STRATEGI PEMASARAN
}

\author{
Oleh:
}

\author{
Shinta Jeanette Camelia Wangke
}

Faculty of Economy and Business

University of Sam Ratulangi Manado

Email: $\underline{\text { snta@snta.us }}$

\begin{abstract}
Abstrak
Corporate Social Responsibilities (CSR) merupakan "Suatu komitmen yang berkelanjutan dari suatu perusahaan untuk berperilaku etis dan berkontribusi secara positif kepada karyawannya, komunitas dan lingkungan sekitarnya, serta masyarakat luas.” Tujuan penelitian ini, apakah penerapan CSR dalam perusahaan dapat dijadikan sebagai strategi pemasaran berdasarkan persepsi konsumen. Penelitian menggunakan pendekatan penelitian kuantitatif dengan metode eksperimen, teknik pengumpulan data dilakukan dengan angket tertutup menggunakan jawaban skala Likert. Data yang terkumpul dianalisis menggunakan uji hipotesis beda dua rata-rata populasi. Penelitian menunjukan; CSR dibandingkan dengan produk maka tidak terdapat perbedaan yang signifikan antara keduanya. Sedangkan CSR ketika dibandingkan dengan harga dan promosi maka terdapat perbedaan yang signifikan. Statistic uji Z diketahui konsumen lebih tertarik terhadap produk dengan program CSR daripada produk tanpa program CSR. Berdasarkan analisis karakteristik sampel terhadap produk dengan program CSR, diketahui kelompok konsumen wanita, kelompok konsumen usia 35-44 tahun, kelompok konsumen dengan pendidikan minimal SMA dan kelompok konsumen dengan penghasilan perbulan diatas Rp. 10.000.000 merupakan konsumen yang paling tertarik dengan produk dengan program CSR. Dapat disimpulkan CSR dapat dijadikan sebagai strategi pemasaran yang efektif, memberikan nilai tambah bagi produk itu sendiri. Apabila dilaksanakan secara berkesinambungan dan disinergikan bersama strategi pemasaran lainnya dapat memberikan dampak yang lebih signifikan keberlangsungan hidup suatu produk.
\end{abstract}

Asbtract

Corporate Social Responsibilities (CSRs) in essence are "Sustained commitments by a company to act ethically and contribute positively to its workers, community, and environment, as well as to the general public." Based on that assumption, it was decided to study whether the implementation of CSRs by a company could be considered as a marketing strategy from the point of view of its customers. This research utilized a quantitative research approach combined with an experimental method, whereas data collection was performed using closed questionnaires with Likert scale-type answers. A hypothesis test was then used to analyze the collected data in order to find out statistical differences between the population means or two population medians. The result showed that when CSRs were compared to product, there was no significant differenece between them. When CSRs were compared to price and promotion, there was a significant difference between them. The Z-test showed that customers were more attracted to products with CSR programs than to products without CSR program even those with lower prices or bundled with promotional offers. Based on sample characteristics analysis on products with CSR programs, it was found that female consumer group, 35-44 year old consumer group, consumer groups with at least senior high school diplomas and consumer group with minimum income of RP.10.000.000,- wereones who were most attracted to products with CSR programs. From the results, it was concluded that CSRs could be an effective marketing strategy because they added values to products. CSRs, when performed continuously and synergized with other marketing strategies, could produce a more significant impact on the success and continuity of a product. 


\section{LATAR BELAKANG MASALAH}

Kesadaran Pentingnya mempraktekan CSR menjadi tren seiring dengan semakin maraknya kepedulian masyarakat global terhadap produk-produk yang ramah lingkungan. Dunia usaha semakin menyadari bahwa perusahaan tidak lagi dihadapkan pada tanggung jawab yang berpijak pada single bottom line, yaitu perusahaan (corporate value) yang direfleksikan kepada kondisi keuangan saja, namun juga harus memperhatikan aspek sosial dan lingkungannya. Dunia usaha bukan lagi sekedar kegiatan ekonomi yang menciptakan profit demi kelangsungan usahanya, melainkan juga tanggung jawab terhadap sosial da lingkungan. Dasar pemikirannya, menggantungkan semata-mata pada kesehatan finansial tidak akan menjamin perusahaan bisa tumbuh secara berkelanjutan. Keberlanjutan perusahaan akan terjamin apabila perusahaan memperhatikan dimensi lainnya, termasuk dimensi sosial dan lingkungan. Fakta menunjukan resistensi masyarakat sekitar muncul ke permukaan terhadap perusahaan yang dianggaptidak memperhatikan faktor sosial dan lingkungan

Menghadapi tren tersebut, perusahaan mulai melihat serius pengaruh dimensi sosial dan lingkungan pada setiap aspek bisnisnya, karena aspek-aspek tersebut bukan suatu pilihan yang terpisah, melainkan berjalan beriringan untuk meningkatkan keberlanjutan operasi perusahaan. CSR bukan lagi dilihat sebagai sentra biaya(cost centre) melainkan sebagai sentra laba (profit). Banyak perusahaan hanya menjalankan kegiatan donasi sebagai aktivitas CSR perusahaannya. Padahal ada banyak aktifitas CSR yang bisa dilakukan selain kegiatan donasi, dan bahkan bisa dilakukan secara menyenangkan terkait dengan aktifitas marketing.

CSR dapat menjadi batu ujian terhadap merek, dilihat dari kemampuannya menongkrak citra suatu merek. Bahkan jika CSR dikemas dalam program yang berkesinambungan diyakini mampu menjadi alat marketing yang ampuh (Simatupang, 2007)

\section{TINJAUAN PUSTAKA}

\section{Corporate Social Responsibilities (CSR)}

CSR diartikan sebagai niat baik dan komitmen dari perusahaan untuk memberikan kontribusi terhadap peningkatan kualitas hidup masyarakat, keberlanjutan pengembangan masyarakat, ekonomilokal sehingga meberikan kontribusi terhadap keberlanjutan perusahaan (Rachman, 2005)

\section{Produk}

Produk adalah segala sesuatu yang dapat ditawarkan kesuatu pasar untukmemenuhi keinginan dan kebutuhan. (Kotler, 2003)

\section{Harga}


Harga adalah dalam arti yang paling sempit merupakan sejumlah uang yang dibayarkan atas barang dan jasa. (Kotler dan Amtrong, 2004)

\section{Promosi}

Promosi adalah penyampaian informasi daripenjual kepada pembeli untuk mempengaruhi sikap-sikap dan tingkah laku. (McCarthy, 1985)

\section{Strategi Pemasaran}

Strategi Pemasaran adalah suatu rencana yang didesain untuk mempengaruhi pertukaran dalam mencapai tujuan organisasi (Peter, 1996)

\section{METODE PENELITIAN}

\section{Lokasi dan Waktu Penelitian}

Penelitian ini dilakukan di Kecamatan Wanea dengan subyek penelitian, masyarakat Kecamatan Wanea dengan kelompok usia 25-55 tahun. Kelompok usia ini dipilih berdasarkan penelitian The Changing Demographic and Consumer Paterns yang mengemukakan bahwa 75\% pembelian retail dilakukan oleh kelompok usia ini (www.bcsc.org.uk). Penelitian ini dilakukan selama 4 bulan, yaitu dari Juli 2013November 2013.

2. Metode dan Desain Penelitian

Penelitian ini menggunakan pendekatan penelitian kuantitatif dengan metode eksperimen. Menurut Suharsimi (2005), penelitian kuantitatif berciri-khas menstrukturkan hubungan antar faktor atau mengklarifikasi hubungan antar faktor. Metode eksperimen menurut Kuncoro (2003) merupakan satusatunya metode penelitian yang benar benar menguji hipotesis mengenai hubungan sebab akibat. Tujuan dari metode eksperimen adalah keyakinan bahwa penelitian eksperimental yang dilakukan merupakan sebab dari suatu akibat yang sedang dievaluasi (Kuncoro, 2003)

\section{Populasi dan Sampel}

Populasi dari penelitian ini adalah kelompok ussia 25-55 tahun yang berdomisili di kecamatan wanea. Penelitian ini menggunakan sample probabilitas dengan jenis desain sampel random sederhana. Menurut Kuncoro (2003) jumlah sampel perkelompok dalam desain penelitian eksperimen adalah 15orang per kelompok. Dalam penelitian ini jumlah sampelnya adalah 120orang, dimana dibagi menjadi 6 kelompok dengan masing-masing kelompok 20 orang.

4. Instrumen dan Metode Pengumpulan Data

Penelitian ini menggunakan angket tertutup dengan jawabab rating scale dan dengan menggunakan skala likert. 


\section{Analisis Data}

Untuk menganalisa data pada penelitian ini menggunakan uji hipotesis tentang beda dua rata-rata populasi. Selanjutnya untuk mengukur persepsi ditentukan dengan statistic uji Z.

\section{HASIL PENELITIAN DAN PEMBAHASAN}

Keseluruhan sampel yang berjumlah 120 orang dibagi menjadi 6 kelompok dengan masing-masing kelompok diberikkan treatment yang berbeda untuk kemudian mengetahui apakah ada terdapat perbedaan yang signifikan antara kedua kelompok untuk kemudian dilakukan uji Z untuk mengetahui persepsi konsumen antara kedua kelompok tersebut.

\begin{tabular}{|l|l|}
\hline CSR dan Produk & Treatment \\
\hline Eksperimen I & $\begin{array}{l}\text { Produk dengan program CSR yang berkualitas } \\
\text { standar } \\
\text { Eksperimen II }\end{array}$ \\
\hline CSR dan Harga & Treatment \\
\hline Eksperimen III & $\begin{array}{l}\text { Produk mahal dengan program CSR } \\
\text { Eksperimen IV }\end{array}$ \\
\hline CSR dan Promosi & Treatment \\
\hline $\begin{array}{l}\text { Eksperimen V } \\
\text { Eksperimen VI }\end{array}$ & $\begin{array}{l}\text { Produk dengan program CSR } \\
\text { Produk dengan program promosi penjualan }\end{array}$ \\
\hline
\end{tabular}

CSR - Produk

Kelompok Eksperimen 1 dan 2

Akan dilihat bagaimana persepsi konsumen terhadap produk dengan program CSR dan produk tanpa program CSR tapi lebih baik dalam hal kualitas produk. Hipotesisnya dinyatakan sebagai berikut: Hipotesis 1 Konsumen lebih menyukai produk standar dengan program CSR dibandingkan dengan produk yang kualitasnya diatas standar tanpa program CSR

Uji Hipotesis ini digunakan untuk menguji apakah ada perbedaan antara dua kelompok eksperimen ini. Dengan taraf signifikasi 0.05 dan hasil $\mathrm{Z}=-1.9230$ menunjukan bahwa tidak terdapat perbedaan yang signifikan antara kelompok eksperimen 1 dan kelompok eksperimen 2 
CSR - Harga

Kelompok Eksperimen 3 dan 4

Selanjutnya ingin dilihat persepsi konsumen terhadap produk dengan program CSR yang harganya lebih mahal dan produk tanpa program CSR dengan harga murah. Hipotesisnya kemudian dinyatakan sebagai berikut:

Hipotesis 2 Konsumen lebih tertarik pada produk mahal dengan program CSR dibandingkan dengan produk yang murah tanpa program CSR

Dengan taraf sinifikasi 0.05 dan hasil $\mathrm{Z}=3.728$ sehingga hipotesis yang menyatakan tidak ada perbedaan rata-rata antara kedua populasi sampel ditolak. Hal ini berarti bahwa terdapat perbedaan yang signifikan antara kedua kelompok eksperimen ini, sehingga uji Z kemudian dilakukan. Pengujian 2 arah dilakukan dengan kesimpulan bahwa populasi sampellebih tertarik untuk membeli produk mahal dengan program CSR

\section{CSR- Promosi}

Kelompok Eksperimen 5 dan 6

Untuk melihat persepsi konsumen antaraea CSR dan Promosi maka hipotesisnya dinyatakan sebagai berikut:

Hipotesis 3 Konsumen lebih tertarik dengan produk tanpa promosi tetapi memiliki program CSR dibandingkan produk dengan promosi tetapi tanpa program CSR

Uji hipotesis digunakan untuk menguji apakah ada perbedaan antara dua kelompok eksperimen ini. Dengan hasil $\mathrm{Z}=2.941$ terdapat perbedaan yang signifikan antara kedua kelompok eksperimen ini dan dengan pengujian dua arah diketahui populasi sampellebih tertarik untuk membeli produk tanpa promosi tetapi memiliki program CSR dibandingkan dengan promosi tetapi tanpa menggunakan program CSR

\section{PEMBAHASAN}

\section{CSR dan Bauran Pemasaran}

a. CSR - Produk. Berdasarkan hasil uji eksperimen 1 dan 2, dapat diketahui bahwa tidak ada perbedaan yang signifikan antara CSR dan Kualitas, kelompok eksperimen 1 dan 2 menjelaskan konsumen pada umumnya mempunyai ketertarikan yang sebanding antara CSR dan Kualitas. Hal ini memberikan gambaran bahwa kosumen tidak dapat mengorbankan kualitas yang bisa didapatkannya dalam suatu 
produk untuk suatu hal yang bersifat kepedulian dan tanggung jawab sosial. Kualitas produk berbicara mengenai apa yang ditawarkan suatu produk untuk pemenuhan kebutuhan individu maupun kelompok. Hal ini mendukung teori kebutuhan Maslow yang mengemukakan bahwa pemenuhan kebutuhan pribadi akan lebih baik diprioritaskan dibandingkan dengan kebutuhan-kebutuhan yang lain.

Hasil ini sejalan dengan Kottler (2006) dalam bukunya yang berjudul 'according to Kottler', menurut Kotler konsumen akan senang membli produk dengan program CSR didalamnya, sejauh tidak ada perbedaan yang mencolok antara kedua produk tersebut.

Implikasi dari hasil ini perusahaan dapat mempertimbangkan untuk secara bersama-sama menonjolkan kualitas dan program CSR dalam suatu produk. Program CSR bila disinergikan dengan strategi pemasaran lainnya dapat menghasilkan dampak yang lebih besar.

b. CSR - Harga. Dari Hasil uji hipotesis terhadap eksperimen 3 dan 4 menunjukan konsumen lebih tertarik kepada produk dengan harga yang lebih mahal tetapi peduli lingkungan. Sehingga dapat disimpulan bahwa produk dengan program CSR walupun lebih mahal tapi lebih diminati konsumen dibandingkan dengan produk yang lebih murah tanpa program CSR.

Hasil penelitian ini senada dengan pendapat Kottler (2006) yang mengemukakan bahwa harga menjadi tidak masalah sejauh tidak terdapat perbedaan yang mencolok. Harga dari suatu produk bagi sebagian orang relative, untuk masyarakat golongan menengah keatas, dan berpendidikan tinggi tidak terlalu memperdulikan harga produk yang dijual walaupun lebih mahal asalkan produk tersebut ramah lingkungan.

c. CSR- Promosi. Hasil dari eksperimen 5 dan 6 memberikan implikasi bahwa perusahaan dapat mempertimbangkan untuk melakukan program CSR bersama sama dengan promosi. Membuat suatu marketing strategi dengan sinergi anatara CSR dan promosi harus dilaksanakan secara seimbang. Dalam sudut pandang masyarakat, CSR dilihat sebagai 'niat baik' perusahaan kepada lingkungannya sedangkan promosi dipandang masyarakat sebagai cara perusahaan untuk memaksimalkan keuntungan. Menjadi hal yang krusial apabila perusahaan salah mempergunakan program CSR sebagai alat promosi semata. Contohnya dengan munculnya puluhan 'iklan' kedermawanan di berbagai media cetak dan elektronik, mulai dari aksi pemberian dana, pembagian produk dan makanan, pemeriksaan kesehatan gratis, sampai servis cuma-Cuma bagi barang yang terkena banjir. Perusahaan rela mengeluarkan biaya jutaan rupiah untuk mengiklankan kegiatan kedermawanannya di media massa. Bahkan dalam beberapa kasus, jumlah donasi yang diberikan jauh lebih kecil dari dana yang dialokasikan untuk mempromosikan kegiatan terebut. Selain menyumbang pada saat yang sama perusahaan juga memanfaatkan momen bencana banjir untuk berpromosi. 
Walaupun dianggap sah dalam kacamata bisnis, strategi dagang semacam itu tentu tidak dapat dibenarkan secara etis. Tidak menutup kemungkinan bahwa nantinya promosi semacam ini menjadi tidak efektifdan justru menjadi boomerang terhadap perusahaan. Imej perusahaan ataupun produk yang ditawarkan bisa rusak karena dianggap tidak punya sense of crisis dan berpromosi disaat yang kurang tepat. Ekspos yang berlebihan terhadap kegiatan sosialperusahaan juga bisa mencederai kegiatan kedermawanan yang sudah dilakukan.

\section{CSR dan Karakteristik Sampel}

a. CSR dan Jenis Kelamin. Berdasarkan jenis kelaminnya konsumen wanita merupakan kelompok konsumen yang paling tertarik dengan produk ini. Hal ini menguatkan pendapat Mangkunegara (2002) dalam buku perilaku konsumen yang mengungkapkan bahwa konsumen wanita merupakan pembeli yang lebih peka dibanding pria.

Implikasi dari hasil penelitian ini bahwa perusahaan dapat mempertimbangkan untuk mengaplikasikan program CSR dalamproduknya, terutama apabila pasar yang dituju adalah pasar untuk wanita.

b. CSR dan Usia. Kelompok usia 35-44 Tahun merupakan kelompok usia yang paling banyak tertarik pada produk dengan program CSR. Kelompok usia ini menurut klasifikasi Verdict Consulting dikelompokan sebagai kelompok usia 'maturing family' dimana pada usia ini konsumen menjadi lebih banyak tuntutan terhadapsuatu produk. Kelompok usia ini menuntut suatu produk untuk mempunyai nilai lebih dari biasanya. Dengan hasil penelitian ini, perusahaan dapat mempertimbangkan untuk mempublikasikan program CSR mereka, agar mendapatkan imej yang positif dari konsumen, sehingga otomatis mendapatkan nilailebih bagi produk mereka.

c. CSR dan Pendidikan. Karakteristik sampel dengan tingkat pendidikan SMU dan PT mempunyai persepsi yang sama terhadap produk dengan programCSR. Berdasarkan hasil ini dapa dilihat bahwa persepsi konsumen antara lulusan SMU dan Perguruan Tinggi terhadapproduk dengan program CSR adalah sama. Hal ini menunjukan bahwa ada faktor-faktor lain bersama sama dengan tingkat pendidikan mempengaruhi persepsi konsumen terhadap suatu produk yang tidak diidentifikasi.

d. CSR dan Pendapatan. Karakteristik sampeldengan pendapatan diatas 10.000.000 rupiah adalah kelompok yang paling tertarik pada produk dengan program CSR. Hal ini menjelaskan teori Sumarwan (2002) bahwa semakin besar pendapatan maka perbedaan harga tidak begitu berpengaruh lagi terhadap preferensi suatu produk.

Berdasarkan Analisis Karakteristik Sampel dan produk dengan program CSR, diketahui bahwa penting untuk mempertimbangkan penerapan CSR sebagai salah satu strategi marketing terutama bagi 
perusahaan yang mempunyai target market wanita, dengan kelompok usia 35-44 tahun dan dengan penghasilan lebih dari 10 juta rupiah. Karena secara bersama-sama karakteristik konsumen ini akan sangat terpengaruh oleh penerapan program CSR dalam suatu produk.

\section{CSR Sebagai Strategi Marketing.}

Berdasarkan hasil uji hipotesis bahwa penerapan program CSR dapat mempengaruhi pembentukan persepsi konsumen terhadap suatuproduk. Penerapan program CSR dapat memberikan nilai tambah terhadap suatu produk dimata konsumen. Marketing strategi adalah bagaimana cara membentuk persepsi akan suatu produk, oleh karena itu dapat dikemukakan bahwa CSR dapat dijadikan sebagai strategi marketing.

Hasil penelitian ini sejalan dengan Porter dkk (http://harvardbusinessonline.hbsp.harvard.edu) yang membuktikan bahwa program-program CSR yang disinergikan dengan strategi marketing akan memberikan dampak yang lebih besarkepada masyarakat dibandingkan dengan program-program CSR ala kadarnya. Pengelolaan CSR secara professional akan memberikan manfaat penguatan bagipencapaian tujuan perusahaan.

Penerapan CSR sebagai strategi Marketing adalah merupakan suatu upaya untuk menjaga sustainability suatu produk. CSR sebagai marketing strategi secara langsung maupun tidak langsung dalam waktu yang cepat atau lambat dapat dipastikan akan mampu diperoleh dampak positifnya.

\section{KESIMPULAN DAN SARAN}

Berdasarkan hasil penelitian persepsi responden terhadap CSR sebagai strategi pemasaran diketahui bahwa:

1.Tidak terdapat perbedaan yang signifikan antara persepsi responden terhadap CSR maupun Produk sebagai strategi pemasaran

2. Terdapat perbedaan persepsi antara CSR dengan Harga sebagai strategi pemasaran. Responden lebih tertarik untuk membeli produk denngan program CSR dibandingkan dengan produk yang lebih murah tanpa program CSR.

3. Terhadap perbedaan persepsi antara CSR dengan Promosi sebagai strategi pemasaran, responden lebih tertarik untuk membeli produk dengan program CSR dibandingakan produk dengan promosi penjualan.

4. CSR dapat menjadi salah satu variable pembentuk bauran pemasaran 
5. Berdasarkan kajian persepsi responden terhadap CSR dan Variabel-variabel Bauran Pemasaran, maka diketahui bahwa CSR dapat diijadikan sebagai strategi pemasaran

Saran

1. Untuk Penerapan CSR sebagai strategi pemasaran perusahaan tidak disarankan untuk lebih menonjolkan program CSR dibandingkan dengan kualitas produk, karena berdasarkan penelitian ini, tidak terdapat perbedaan persepsi antara keduanya sehingga akan jauh lebih baik apabila disinergikan secara bersama-sama.

2. Berdasarkan persepsi responden makan penerapan CSR dan Harga sebagai strategi pemasaran dapat dilakukan sejau tidak terdapat perbedaan yang mecolok antara harga produk dengan program CSR dan harga produk tanpa program CSR.

3. Penerapan CSR dan Promosi dapat disinergikan sejauh dilakukan secara wajar dan professional.

4. Untuk menjadikan CSR sebagai salah satu variable pembentuk bauran pemasaran maka dana untuk program CSR harus berasal dari profit perusahaan yang disisihkan, dan bukan merupakan biaya yang menjadi beban perusahaan

5. Dengan melihat ketertarikan konsumen terhadap produk dengan muatan program CSR, perusahaan dapat mensinergikan program CSR dengan bauran pemasaran lainnya secara bersama sama untuk mendapatkan dampak yang lebih signifikan terhadap suatu produk. Untuk kemudian menjadikan CSR sebagai strategi pemasaran yang efektif, perusahaan harus mempunyai komitmen untuk membuat suatu program CSR yang sustainable dalam rangka meraih tujuan dari perusahaan itu sendiri.

\section{DAFTAR PUSTAKA}

Afiff F. 1981. Perilaku Konsumen. Alfabeta. Bandung

Alma B. 2005. Manajemen dan Pemasaran Jasa. Alfabeta. Bandung

Assauri. 2002. Marketing Management : Analisis, Planning and Control. Erlangga.

Jakarta Atmajaya L. 1997. Memahami Statistika Bisnis. Andi Offset. Yogyakarta

Boone L. and D. Kurt. 1987. Contemporary Marketing. The Prydon Press. New York

Chang Y. and F. Campo. 1980. Business Policy and Strategy. Goodyear Publishing Company, Pasific Palisades, CA

Cortada J. 1996. TQM for Information System Management. McGraw Hill Higher Education. New

York Ernawan E. 2007. Business Ethics. CV. Alfabeta. Bandung

Go J. 1996. Marketing Mix. Josiah Go Foundation. Manila Filipina 
Guiltiman J. and G. Paul. 1980. Marketing Management Strategies and Programs. McGraw Hill Book Company. New York

Hadi S. 1994. Statistika I. Andi Offset. Yogyakarta

Hill C. and G. Jones. 2006. Strategic Management. Houghton Mifflin. Houston

Irianto A. 2003. Statistik Konsep Dasar dan Aplikasinya. Kencana. Jakarta

Jauch L. and W. Glueck. 1984. Bussines Policy and Strategic Management. McGraw Hill Higher Education. New York

Johnson G. and K. Scholes. 1998. Evaluation in Strategic Management. Prentice Hall. New

Jersey Kartajaya H. 2006. MARKETing. PT. Gramedia Pustaka Utama. Jakarta Keegen W.

1998. Manajemen Pemasaran Global. Prenhalindo. Jakarta

Kotler P. 2003. Marketing Management. Prentice Hall, Pearson Education International. New Jersey

Kotler P. 2006. According To Kotler. PT. Bhuana Ilmu Populer. Jakarta Kotler P. and G. Amstrong.

2004. Marketing Prentice Hill. New Jersey

Kotler P. H. Kartajaya, Hooi Den Huan, and S. Liu, 2005. Rethingking Marketing. PT Indeks.

Jakarta Kotler P. and N. Lee 2005. Corporate Social Responsibilities. John Wiley \& Sons, Inc.

New Jersey

Kotler P. and A. Susanto. 2000. Manajemen Pemasaran Di Indonesia: Analisis, Perencanaan, Implementasi dan Pengendalian. Salemba Empat. Jakarta

Kuncoro M. 2003. Metode Riset untuk Bisnis \& Ekonomi. Erlangga.

Jakarta Mangkunegara A. 2002. Perilaku Konsumen. Refika Aditama.

Bandung McCarthy J. 1985. Basic Marketing. McGraw Hill Education.

New York

McDaniel C. and R. Gates. 2001. Riset Pemasaran Konteporer. Salemba Empat.

Jakarta Mintzberg H. 1998. Strategic Management. Financial Times, Prentice Hall.

Jakarta Pagoso C. and G. Garcia. 1990. Fundamental Statistics. Sinagtala. Pilipina

Peter P. and J. Olson.1996. Perilaku Konsumen dan Strategi Pemasaran. Erlangga. Jakarta 
Rangkuti F. 2002. Marketing Plan. PT. Gramedia Pustaka Utama. Jakarta

Rao V. and J. Steckel. 1997. Analysis for Strategic Management. Prentice Hall. New Jersey

Rachman N. 2005. CSR dan Pengembangan Ekonomi Lokal. Laporan Workshop CSR Juli 2006.

Bandung

Simatupang D. 2007. CSR For Profit. Marketing No.11/VII/NOVEMBER/2007, hal 39-41. PT. Info Cahaya Hero. Jakarta

Stanton W. 1991. Fundamental of Marketing. McGraw Hill. New York

Stanton W. and H. Lamarto. 1997. Taktik dan Strategi Pemasaran. ANS Sungguh Bersaudara.

Jakarta Sugiono. 1997. Metode Penelitian Administrasi. CV. Alfabeta. Bandung Suharsimi A. 2005.

Prosedur Penelitian. Rineka Cipta. Jakarta

Sutisna. 2001 Perilaku Konsumen dan Komunikasi Pemasaran. PT. Remaja Rosdakarya.

Bandung Sutrisno H. 1994. Statistik. Andi Offset. Yogyakarta

Swastha D. 1983. Manajemen Pemasaran Modern. Liberty. Yogyakarta

Swastha D. 2005. Azaz-azaz Marketing Liberty. Yogyakarta

Tjahjono G. 2007. CSR Bukan Untuk Laba Rugi Semata. Marketing No.11/VII/NOVEMBER/2007, hal 42-44. PT. Info Cahaya Hero. Jakarta

Tjiptono F. 2002. Perspektif Management Pemasaran Konteporer. Andi Offset. Yogyakarta

Umar H. 2005. Metode Penelitian Untuk Skripsi dan Tesis Bisnis. PT. Raja Grafindo Persada. Jakarta

WBCSD (2001). The Business Case for Sustainable Development. World Business Council for Sustainable Development

WBCSD (2000). Corporate Social Responsibility: Making good business sense. World Business Council for Sustainable Development.

WBCSD (1999). Corporate Social Responsibility: Making changing expectation. World Business Council for Sustainable Development.

Wibisono Y. 2007.CSR (Corporate Social Responsibilities). Fascho Publishing. Gresik

Windyaningrum A. 2007. Corporate Social Responsibilities. Warta Ekonomi No.

18/XIX/SEPTEMBER /2007, hal. 38-40. PT. Obor Sarana Utama. Jakarta

Zikmund W. and D. Amico.2006. Marketing. Thomson Learning. South Western

http: //www.businessethics.ca diakses pada tanggal 27 Januari 2008 pkl 19.36 